Status Report 2016-2019

\title{
Magmatic and Hydrothermal Ore Deposits
}

\author{
BISWAJIT MISHRA* \\ Department of Geology and Geophysics, IIT Kharagpur, 721 302, India
}

(Received on 06 September 2019; Accepted on 30 September 2019)

\begin{abstract}
This article briefly reviews all contributions by Indian geoscientists between the period 2015 and 2019, in the field of magmatic and hydrothermal ore deposits. The contributions covered are mainly on deposits and prospects of chromite, PGE, gold and uranium. Very few contributions have been made on base metals. However, experimental sulfide phase equilibrium research, related to metamorphic remobilization of massive sulfides, has continued with its modest initiation.
\end{abstract}

Keywords: Metallic Ore Deposits; India; Research

\section{Introduction}

One book and two review articles, on various aspects of ore deposits were published during the report period. The book entitled "Minerals and allied natural resources and their sustainable development: principles, perspectives with emphasis on the Indian scenario" by Deb and Sarkar (2017) includes all possible natural resources such as metallic and nonmetallic ore deposits, both inorganic and organic energy resources, and two vital resources for human civilization, i.e., water and soil. From the context of this review, the book furnishes a classification of all possible metallic (and non-metallic) ore deposits, their genetic aspects (including tectonic settings), and most importantly Indian examples, apart from classical deposits world over. While Deb and Pal (2015) reviewed the mineral resources of Proterozoic intracratonic basins, the article by Mishra (2015) deals with the Precambrian metallogeny of India.

Scrutiny of the published studies reveals that metals such as Cr, PGE, Au and U continued their earlier momentum. Some studies on chromite and PGE appear to be igneous petrology-centric, which is inevitable while working on magmatic ores. As pointed in the last reports, unlike countries like Australia, Canada and South Africa, industry-academia collaboration, an extremely valuable component in ore deposit research, is still missing. This compilation incorporates all the published work on magmatic (chromite, PGE) and hydrothermal (gold, uranium, $\mathrm{REE}, \mathrm{Nb}-\mathrm{Ta}, \mathrm{W}$, base metals) deposits from India. If some work is missed out, the author expresses regret for such unintended omission.

\section{Chromite and PGE Ores}

From discrimination plots of the REEs, PGEs and other trace elements, of the mafic rocks of east Khasi Hills, Meghalaya Plateau, Hazra et al. (2015) proposed generation of the parental mafic melt by columnar batch melting (up to $25 \%$ ), involving dehydration, wedge-melting and assimilation fractional crystallization process at a continental margin arc setting. The $\mathrm{Re}-\mathrm{Os}$ isotope systematics of the chromitites and associated websterites and anorthosites were studied in the layered Chimalpahad Anorthosite Complex that occurs within the Peninsular Gneissic Complex. The average initial ${ }^{187} \mathrm{Os} /{ }^{188} \mathrm{Os}$ composition (and $\gamma$ Os values) of chromite, websterites and anorthosites were found to be 0.1045 (-17.67), $14.86(+467)$, and $11.79(+215)$ respectively. Mantle extraction ages of the chromites point to depletion of primitive mantle at ca. $\sim 3.5 \mathrm{Ga}$ (Dharma Rao et al., 2015). The molar ratios $\mathrm{Cr} \#$ and $\mathrm{Mg} \#$ in Podiform chromite of the Manipur ophiolite belt range from 6782 and 66-71 respectively. The estimated P-T conditions for chromite crystallization are 19-25 kbar and $1080-1240{ }^{\circ} \mathrm{C}$, with $f \mathrm{O}_{2}$ varying between 0.30

*Author for Correspondence: E-mail:bmgg@iitkgp.ac.in 
and $0.58 \log$ units above the FMQ buffer, implying formation in the upper mantle from a boninite parental magma. The chromite grains contain trail-bound inclusions of silicates, Ni-Fe sulfides and Fe-Ni metals, indicating alteration from a crustal fluid (Maibam et al., 2017).

Jena et al. (2016) identified various platinum group minerals (PGM) such as sudburyite, laurite, sperrylite, braggite, merenskyite, hollingworthite, testibiopalladite, michenerite, malanite, isoferroplatinum in the chromite-base metal sulfide association within Bangur gabbro at Baula-Nuasahi area, Odisha. The PGMs occur as inclusions in chromite, at the silicate-chromite grain boundaries, and within base metal sulfides (chalcopyrite, pyrrhotite, pentlandite). Occurrence of rare greenockite (CdS) associated with chromite-PGE in the Bangur gabbro of the Baula-Nuasahi mafic-ultramafic complex in eastern India was reported by Mishra and Hazarika (2016). This rare phase occurs in siderite-chlorite micro-veinlets without any precursor Cd-bearing phase. The associated chalcopyrite contains high $\mathrm{Cd}$, which is considered as the source for greenockite. Transport of $\mathrm{Cd}$ as bisulfide complex in a low temperature alkaline and reducing fluid resulted in concurrent precipitation of greenockite and siderite postdating the PGE mineralization by reaction with Fe-rich minerals, aided by decrease in $\mathrm{pH}$ and/or increase in $f \mathrm{O}_{2}$.

High $\mathrm{MgO}$ mafic volcanics of the Bababudanand the Gadwal greenstone belts, respectively in the western and eastern Dharwar Craton have been geochemically classified as komatiites and boninites respectively. While the Bababudan komatiites have low $\Sigma$ PGE (9-42 ppb), the Gadwalboninites are characterized by high $\Sigma$ PGE (82-207 ppb). Such strikingly different PGE abundance is interpreted as a result of fractionation of olivine and chromite/sulfide respectively from the parental komatiitic and boninitic melts. The S-under saturated character of Bababudan komatiites is attributed to decompression and assimilation of lower crustal materials during magma ascent and emplacement. In contrast, geochemical features such as higher $\mathrm{Al}_{2} \mathrm{O}_{3}$ and $\mathrm{Pd}$ contents, lower $\mathrm{Cu} / \mathrm{Pd}(\mathrm{Gd} / \mathrm{Yb})_{\mathrm{N}}$ values, and negative $\mathrm{Nb}-, \mathrm{Zr}-, \mathrm{Hf}$, Ti anomalies of the boninites imply high degree of $\mathrm{H}_{2} \mathrm{O}$ saturated melting of the refractory mantle wedge, wherein influx of subduction-derived fluid and sulfide retention in the residual mantle were contributory factors for their S-under saturation (Saha et al., 2015).

Palladium contents of 1-3 ppm (average $\mathrm{Pt} / \mathrm{Pd}$ $=0.15$ ) have been reported from a layered magnetitite in the Archean layered Nuasahi Massif (Odisha). The first formed, primary assemblage of platinum-group minerals (PGM) contains Pd-sulfides [vysotskite, (Pd,Ni)S], $\mathrm{Pd}-\mathrm{Pb}$ alloys (zvyagintsevite, $\mathrm{Pd}_{3} \mathrm{~Pb}$ ), and a Pd-In alloy. These central magnetite grains are commonly surrounded by blebs of ilmenite and magnetite that contain the majority of the PGM. These are dominated by Pd-antimonides, apart from $\mathrm{PtAs}_{2}$ (sperrylite), $\mathrm{RuS}_{2}$ (laurite), and IrRhAsS (irarsite/ hollingwothite). These PGMs also occur in the interstitial silicates, with rare occurrences in the central magnetite grains. Prichard et al. (2018) proposed that the PGEs, along with minor $\mathrm{Cu}$-sulfides, crystallized during a minor sulfide saturation event that occurred as the magnetitites crystallized. Later fluid-assisted introduction of $\mathrm{Sb}$ and As produced the main PGM assemblage, dominated by $\mathrm{Pd}$-antimonides, associated with secondary $\mathrm{Cu}$ minerals and sperrylite. The $\mathrm{Pd}$ mineralization in the magnetitites constitutes the third stage PGE concentration at a higher stratigraphic level, in the layered Nuasahi Massif, besides the lower, twostage concentrations in chromitites.

The layered ultramafic unit in the Mesoarchean Sukinda Massif comprises serpentinized dunite, orthopyroxenite and chromitite, apart from brecciated ultramafic rocks cemented by gabbro-granodiorite clasts. The positive correlation between $\mathrm{MgO}$ and $\mathrm{Ni}$, and $\mathrm{MgO}$ and $\mathrm{Cr}$ in these rocks is due to fractionation of early cumulus olivine/chromite from the high-Mg parental magma (Mondal et al., 2019). While the correlation between $\mathrm{Zr}$ and $\mathrm{Cu}$ suggests that the parental boninitic magma was S-under saturated, the flatter trend in the $\mathrm{Zr}-\mathrm{Cu}$ plot from the matrix gabbro indicates sulfide saturation to have occurred later in the evolved boninitic magma. The $\Sigma$ PGE content in the ultramafic-hosted massive chromitites $(\approx 176-875 \mathrm{ppb})$ and in breccia-hosted chromitite fragments $(\approx 61-279 \mathrm{ppb})$ are higher than the serpentinite $(\approx 19-71 \mathrm{ppb})$, orthopyroxenite $(\approx 14$ $19 \mathrm{ppb})$ and gabbro ( $\approx 3-11 \mathrm{ppb})$. Further, there is a relative enrichment of IPGE ( $\mathrm{Ir}+\mathrm{Os}+\mathrm{Ru} \approx 528$ $634 \mathrm{ppb})$ over PPGE (Pd $+\mathrm{Pt}+\mathrm{Rh} \approx 93-332 \mathrm{ppb})$, which is manifested by dominance of Os-Ir-Ru (+ 
minor Pt) alloys besides laurite $\left(\mathrm{RuS}_{2}\right)$, irarsite (Ir, $\mathrm{Ru}, \mathrm{Rh}, \mathrm{Pt}) \mathrm{AsS}$, and sperrylite $\left(\mathrm{PtAs}_{2}\right)$ in chromite. The IPGE vs. $\mathrm{MgO} / \mathrm{Cr}$ plot indicates fractionation during the early stage of magmatic differentiation from a S-under saturated boninitic magma. Dominance of the Os-Ir-Ru alloys suggestive crystallization at high temperature and low $f \mathrm{~S}_{2}$ within a S-under saturated boninitic magma ascending from the upper mantle. This study reveals potential for PGE mineralization in the Sukinda area, possibly an extension of the neighboring Baula-Nuasahi area (Mondal et al., 2019).

The 3.1 Ga IOG mafic volcanics from the Jamda-Koira Iron Ore basin of the Singhbhum Craton and Paleoproterozoic Malangtolivolcanics exhibit calcalkaline and tholeiitic to calc-alkaline compositional characters respectively, despite greenschist to lower amphibolite facies metamorphic overprinting. PGE abundance in the IOG volcanics was controlled by sulfide fractionation, whereas that in the Malangtoli samples is ascribed to chromite and sulfide fractionations. The S-saturated, PGE depleted character of the IOG volcanics implies low degrees of partial melting, followed by crustal contamination. Variable degrees of partial melting and crustal contamination account for the S-saturated to under saturated nature of the Malangtoli basalts having a wide variation in their PGE contents (Singh et al., 2016). Geochemical features such as the Fe-rich nature and high $\mathrm{fO}_{2}$ condition did not favor sulfide saturation during magma evolution in the Deccan province, unlike the Siberian continental flood basalts. Further, crustal contamination also failed to increase the sulfur budget ( $c f$. Laxman and Vijay Kumar, 2018). Although the Deccan rocks lack $\mathrm{Cu}$ sulfide mineralization, these authors suggest that they may contain native $\mathrm{Cu}$ mineralization.

\section{Gold}

Hazarika et al. (2015a) carried out monazite U-Th$\mathrm{Pb}_{\text {total }}$ dating and rigorous $\mathrm{P}-\mathrm{T}$ pseudosection analyses for the Hutti-Maski greenstone belt (HMGB) and the south Kolar greenstone belt (SKGB) to assess their metamorphic and geochronological evolution. The estimated timings of felsic volcanism for the HMGB and the SKGB rocks are ca. $2669 \pm 22 \mathrm{Ma}$ and 2661 \pm 32 Ma respectively. The HMGB rocks underwent mid-amphibolite facies metamorphism at ca. $2564 \pm$ $12 \mathrm{Ma}$ with peak P-T of $\sim 6 \mathrm{kbar}$ and $\sim 620^{\circ} \mathrm{C}$. The
SKGB greenstones, on the other hand, experienced a lower amphibolite facies metamorphism at ca. 2546 $\pm 12 \mathrm{Ma}$ and the peak P-T reached $\sim 4.6 \mathrm{kbar}$ and $\sim 600^{\circ} \mathrm{C}$. A pervasive post-peak metamorphic K-rich fluid alteration event is recorded at ca. $2414 \pm 18 \mathrm{Ma}$ in the HMGB, which is similar to a post-metamorphic shear-induced hydrothermal activity at ca. $2414 \pm 26$ Ma from the SKGB. These two late Archean greenstone belts are $\sim 100 \mathrm{Ma}$ younger and metamorphosed to higher grades than their counterparts in the Abitibi province and the Yilgarn Craton.

A combined EPMA-LA-ICP-MS study concerning analysis of major and trace elements intexturally constrained tourmalines from alteration zones at Hutti and Hira-Buddini was undertaken, in order to compare and evaluate possible fluid sources related to tourmaline precipitation during gold mineralization (Hazarika et al., 2015b). Tourmaline composition show evolutionary trends in compositional space that suggest a single low-salinity and reduced metamorphic fluid, with characteristically low $\Sigma$ REE, which was responsible for proximal alteration and attendant gold mineralization at Hutti. The type I and type II tourmalines from Hira-Buddini display oxydravite-povondraite trends, with compositional overlap that implies fluid mixing at a paragenetically early stage. The early hydrothermal fluid was more saline, oxidizing, and had a granite-derived component with high $\Sigma$ REE contents. A later evolved, relatively low-salinity and reduced fluid is recorded by the last generation (type III) tourmalines at Hira-Buddini.

A comprehensive LA-ICP-MS study involving analysis of REE- and other important trace elements in scheelite, apatite, and calcite in two mineralization stages of Hutti was attempted by Hazarika et al. (2016). Scheelite displays three types of REE patterns, which include type-I MREE-enriched with negative Eu-anomaly (stage-1), type-II HREE-enriched with minor positive/negative Eu-anomaly, and type-III varying from slightly MREE-enriched to MREEdepleted with corresponding increase in positive $\mathrm{Eu}-$ anomaly (stage-2). The occurrence of minute MREEenriched scheelite grains in the stage-1 mineralization assemblage is attributed to high ambient temperature $\left(475^{\circ} \mathrm{C}\right)$, while abundant scheelite precipitation during stage- 2 was aided by decrease in temperature $(\sim 300$ ${ }^{\circ} \mathrm{C}$ ) and further abetted by fluid pressure fluctuations 
due to fault-valve action. The MREE-depleted patterns of stage- 2 scheelites, do not necessarily indicate a precipitation from a different fluid, but are due to MREE removal in early formed scheelites. The close system REE behavior is further supported by REE conservation in the altered rocks. Tourmalines from both the stages have low contents of $\mathrm{Na}$, LILEs, HFSEs and comparably low $\mathrm{Fe}^{3+} / \mathrm{Fe}^{2+}$ ratios, suggesting analogous nature of the two fluids of metamorphic parentage, contrary to the proposed twofluid model of Rogers et al. (2013) for the Hutti deposit.

Raman spectroscopic studies performed on gaseous inclusions in auriferous quartz veins from the inner and proximal zones of the Jonnagiri granitoidhosted gold deposit, confirm presence of disordered graphite, occurring as thin films within fluid inclusions, apart from variable proportions of $\mathrm{CO}_{2}, \mathrm{CH}_{4}$ and $\mathrm{H}_{2} \mathrm{O}$. Computed Perple_X -aided phase diagram in the $\mathrm{C}$ $\mathrm{O}-\mathrm{H}$ system at $300{ }^{\circ} \mathrm{C}$ and $2 \mathrm{kbar}$ explain chemical evolution of the C-O-H fluids. The estimated $f \mathrm{O}_{2}$ values on the graphite saturation surface range from $10^{-35.71}$ to $10^{-32.65}$, when $\mathrm{X}_{\mathrm{O}}$ varies from 0.1 to 1.0 . However, $f \mathrm{O}_{2}$ decreases drastically to $10^{-49.31}$ at $\mathrm{X}_{\mathrm{O}}=$ $0.1 \mathrm{E}-07$, where almost pure $\mathrm{CH}_{4}$ is stable. Decrease in $\mathrm{fO}_{2}$, as demonstrated by the occurrence of gaseous fluid inclusions with disordered graphite and varying proportions of $\mathrm{CO}_{2}-\mathrm{CH}_{4}$ in the gaseous part, acted as the causative factor in decreasing gold solubility during fluid-rock interaction and precipitating gold from a metamorphic fluid at Jonnagiri (Chinnasamy and Mishra, 2017). On the contrary, the $\delta^{13} \mathrm{C}$ - and $\delta^{18} \mathrm{O}$ values, along with pertinent trace element geochemical features of carbonates in the auriferous quartzcarbonate veins from Jonnagiri have been interpreted to imply mantle and/or juvenile magmatic source of the ore fluid (Kesarwani et al., 2019). Further, these authors propose that the Jonnagiri deposit is similar to the granitoid-hosted gold deposits in the Jiadong Peninsula, North China craton, characterized by nonmetamorphic (magmatic) fluid source, contrary to previous studies on Jonnagiri (Chinnasamy and Mishra, 2013) and many granitoid-hosted orogenic gold deposits, elsewhere in the world (Saravanan et al., 2009). Swain et al. (2015) undertook a C- and Oisotopic study of carbonates in auriferous quartzcarbonate veins from various mines in the Gadag Gold Field, western Dharwar Craton. The above authors argued that this set of calculated C-isotopic composition could not have resulted by metamorphic devolatilization of greenstones and they rather reflect mantle/magmatic derived $\mathrm{CO}_{2}$ or carbonates. Further, in a more recent study involving $\delta^{13} \mathrm{C}, \delta^{18} \mathrm{O}$ and $\delta^{34} \mathrm{~S}$ and geochemistry of auriferous quartz-carbonate veins in the Ajjanahalli and Gadag gold deposits (western Dharwar Craton), Swain et al. (2018) proposed mantle-derived gold mineralizing fluid. However, it is worth noting that the $\mathrm{C}$-isotope compositions of carbonates act as tracers of carbon, not of the ore fluid (see McCuaig and Kerrich 1998).

Turbidite-hosted auriferous zones in the Gadag greenstone belt contain quartz, ankerite, chlorite, sericite, carbonaceous matter, with minor plagioclase, monazite and xenotime. The associated ore minerals are arsenopyrite, pyrite, pyrrhotite, chalcopyrite, sphalerite, galena, scheelite; and gold occurs within quartz and arsenopyrite. LREE-enriched REE pattern of altered wall rocks with prominent negative $\mathrm{Eu}$ anomaly point to differential response of the host rock and intensity of alteration depending on the composition of the host rocks and hydrothermal fluids. The ore fluids were of low salinity (2.0 to $6.6 \mathrm{wt}$. \% $\mathrm{NaCl}$ equiv.) of metamorphic parentage with $30 \mathrm{~mol}$ $\% \mathrm{CO}_{2}$, and gold precipitation occurred over a wide temperature range $\left(175{ }^{\circ} \mathrm{C}-325{ }^{\circ} \mathrm{C}\right)$, as a result of fluid mixing, phase separation and redox reactions (Ugarkar et al., 2016). Mineral association and major/ trace element chemistry of magnetite and apatite from the albitite- and carbonate-hosted Bhukia gold-Cu deposit point towards an analogous iron oxide copper gold-iron oxide apatite (IOCG-IOA) ore forming setting in the Aravalli-Delhi Fold Belt (Mukherjee et al., 2017).

Based on various major and trace elements, the Kudrekonda meta-volcanic rocks in the Shimoga greenstone belt (western Dharwar Craton) are classified as boninites, with magma generation in an intra-oceanic arc setting by partial melting of a spinel lherzolite mantle source. Gold occurs in Fe-oxides/ quartz in the BIF and the mineralization is of convergent margin orogenic type. Gold mineralization in boninites was a consequence of transportation and precipitation of Au by a metamorphic fluid in shear zones. Au occurs in disseminated sulfide lenses containing pyrite, arsenopyrite, chalcopyrite and minor galena. Epigenetic BIF-hosted gold mineralization is attributed to migration of oxygen depleted, reducing, 
sulfurous-auriferous hydrothermal fluids to the site of BIF deposition that served as chemical traps for the auriferous fluids (Ganguly et al., 2016).

A combined mineralogical, fluid inclusion and $\delta^{13} \mathrm{C}-\delta^{18} \mathrm{O}$ study in auriferous quartz-calcite veins from the Chigargunta and Bisanatham deposits in the south Kolar greenstone belt is recently undertaken by Pal et al. (2019). The estimated ore fluid compositions are low to medium salinity $\mathrm{H}_{2} \mathrm{O}-\mathrm{NaCl}-$ $\mathrm{CO}_{2}-\mathrm{CH}_{4} \pm \mathrm{N}_{2}$ and low salinity $\mathrm{H}_{2} \mathrm{O}-\mathrm{NaCl}$, respectively at Chigargunta and Bisanatham. The ranges in mineralization $\mathrm{P}-\mathrm{T}$ conditions are 1.7-3.5 $\mathrm{kbar} / 285^{\circ}-378^{\circ} \mathrm{C}$ (Chigargunta) and 0.8-1.2 kbar/ $365^{\circ} \mathrm{C}-405^{\circ} \mathrm{C}$ (Bisanatham). Deduced fluid $\delta^{13} \mathrm{C}$ and $\delta^{18} \mathrm{O}$ values suggest derivation by metamorphic devolatilization of marine carbonates within the greenstones.

Nature and source of the ore forming fluids for different orogenic gold deposits/ prospects in the Dharwar Craton is recently reviewed by Mishra et al. (2018). Typical low salinity aqueous-gaseous $\left(\mathrm{H}_{2} \mathrm{O}-\mathrm{CO}_{2} \pm \mathrm{CH}_{4}+\mathrm{NaCl}\right)$ fluid altered diverse host rocks (mafic greenstones, BIF, granitoid) and precipitated gold in a narrow P-T window (0.7-2.5 kbar and $215-320^{\circ} \mathrm{C}$ ). While the estimated fluid $\mathrm{O}$ and $\mathrm{C}$-isotopic values are ambivalent, $\mathrm{S}$-isotopic compositions of the pyrite-precipitating fluids show distinct craton-scale uniformity in terms of its reduced nature and a suggested crustal sulfur source. Chemical composition of tourmaline suggests fluids derived by metamorphic devolatilization reactions of the greenstones (volcanics and interlayered sedimentary rocks), with minor granitic contributions that precipitated gold. Apart from water, the metamorphic fluid had enough sulfur and arsenic, necessary for formation of orogenic gold deposits. Chemistry of scheelite, pyrite and arsenopyrite imply fault-valve action that resulted in pressure fluctuation, which was the causative factor behind gold precipitation, besides wall rock sulfidation reactions (Mishra et al., 2018).

Gold mineralization occurring along the MoyarBhavani shear zone (MBSZ) in the Southern Granulite Terrain at Wynad-Nilgiri, Malappuram and Attappadi has been reported by Sahoo et al. (2016). The Aubearing quartz veins, along with muscovite-calciteankerite-chlorite-biotite-pyrite alteration, occur within the biotite/hornblende bearing gneisses and amphibolite. Fluid inclusion microthermometry in vein quartz suggest low salinity, aqueous-carbonic fluid which underwent phase separation. Rb-Sr and Sm$\mathrm{Nd}$ isochrons of hydrothermal muscovite and calcite yield an age of ca. $450 \mathrm{Ma}$ for the vein formation, which indicates extensive fluid influx during the PanAfrican orogeny along the MBSZ. Gold precipitation took place from such $\mathrm{H}_{2} \mathrm{O}-\mathrm{CO}_{2}-\mathrm{CH}_{4}$ - $\mathrm{Au}(\mathrm{HS})_{2}{ }^{-}$fluid as a result of phase separation and fluid-rock interaction (Sahoo et al., 2016).

Chakravarti et al. (2019) studied the nature and genesis of gold mineralization hosted by radioactive, matrix-supported, oligomictic quartz-pebble conglomerates from the eastern Iron Ore Group and the Dhanjori basin within the Singhbhum Craton. LAICP-MS analysis of various As-bearing pyrites reveals presence of gold (up to $52 \mathrm{ppm}$ ). Gold was initially incorporated in the earliest pyrite due to microbial action and was later leached by hydrothermal fluid leading to increasing concentration in younger pyrites. The above authors proposed a 'modified placer' origin (à la Witwatersrand) for the quartz-pebble conglomerate- hosted gold mineralization in the Singhbhum Craton.

\section{Uranium, REE, Nb, Ta, W ores}

Compositional characteristics of uraninite within the Mahagiri Quartzite (Singhbhum Craton), such as elevated Th content and high $\Sigma$ REE content indicate a high temperature magmatic source. The chemical formulae of the uraninite imply multiple source population and variations in oxidation states. Presence of detrital uraninite indicates existence of highly felsic and K-rich granodiorite-granite-monzogranite suitesof rocks older than $3.1 \mathrm{Ga}$ in the Singhbhum craton (Mukhopadhyay et al., 2016).

A combined fluid inclusion petrographicmicrothermometric study by Pal and Bhowmick (2015) in apatite from the Turamdih U (SSZ) deposit reveals that apatite initially crystallized at $\sim 450^{\circ} \mathrm{C}$ and the high temperature-high salinity fluid mixed with a low temperature fluid with rather lower salinity during the later stage of apatite crystallization. Micron-scale spatial association of apatite with uraninite, monazite and magnetite point towards at least some part of UREE mineralization was cogenetic with apatite. 
Albitite-hosted uranium mineralization within the BGC in Bichun area, Jaipur district, Rajasthan contains minerals such as davidite, brannerite and uraninite. While the davidite $\mathrm{U}-\mathrm{Pb}$ age is ca. $930 \mathrm{Ma}$, the $\mathrm{Sm}-$ $\mathrm{Nd}$ model age $\left(\mathrm{T}_{\mathrm{DM}}\right)$ furnishes a range from 1851 to $2200 \mathrm{Ma}$ with $\varepsilon_{\mathrm{Ndi}(930 \mathrm{Ma})}$ varying between -10.7 to -15.5 , implying the Banded Gneissic Complex (BGC) as the source of uranium (Yadav et al., 2016).

A mineral-chemical study (optical microscopy, Raman spectroscopy and EPM analyses) was performed to assess the alpha radiation and subsequent alteration at the interface of uraninite inclusions in silicate minerals in a migmatitic sample from the Samarkiya area, Bhilwara district, Rajasthan. Important observations include anomalous coloration, reaction aureoles of chlorite (in biotite) and K-feldspar (in plagioclase) and dissolution textures within the matrix monazites. Compositional trends of the reaction aureoles in albitic plagioclase reveals organized distribution of K-feldspar-, LREE- and clay-rich zones; while the same in biotite is composed of secondary chlorite. Such growth sequence of the secondary phases indicates an influx of a K-rich fluid, following intense radiation damage, efficiently superimposed by LREE-metasomatism and later acidic alteration. These changes took place under low-temperature $\left(\leq 150^{\circ} \mathrm{C}\right)$ conditions, wherein radial cracks (within plagioclase) and cleavages/fractures (within biotite) favored fluid infiltration-circulation into the reaction aureoles. Decrease in the LREEs from the matrix monazites and their enrichment as a discrete LREE phase within the damaged aureoles in plagioclase demonstrate micrometer-scale LREE mobility (Ozha et al., 2016). EPMA dating of uraninite from the Samarkiya area, central Rajasthan reveals three distinct ages. While the oldest age of ca.1.88 Ga, obtained from uraninite in the basement, represents the first stage of mineralization, large population of uraninites, both from the basement and the supracrustal, has an age of ca. 1.24-1.20 Ga, which is interpreted to be the major and pervasive event of uranium mineralization. Later, during Neoproterozoic (ca.1.01-0.96 Ga), either some uraninites were altered leading to complete $\mathrm{Pb}$-loss, or new uraninite crystallized/re-crystallized as a result of fresh hydrothermal event. Thus, the area underwent various metamorphic/hydrothermal events resulting in uraninite precipitation, alteration and recrystallization, imprints of which are preserved in uraninites. Further, the three discrete episodes spanning ca. $0.92 \mathrm{Ga}$ represents growth of different generation of uraninite, where the last one pertains to amalgamation of the Rodinia Supercontinent (Ozha et al., 2017).

Rare metal (LCT-type) zoned pegmatites associated with the granites of the Kawadgaon area in the Bastar Craton contain ore minerals such as columbite-tantalite, ixiolite, pseudo-ixiolite, wodginite, tapiolite, microlite, fersmite, euxenite, aeschynite, beryl, cassiterite, monazite, xenotime, zircon, ilmenite, triplite, and magnetite. High initial ${ }^{87} \mathrm{Sr} /{ }^{86} \mathrm{Sr}$ isotopic ratio and other geochemical features of granites indicate their derivation from older crustal rocks. Pegmatites were derived from the granitic melt by fractional crystallization (Singh et al., 2017). Columbite-tantalite furnished $\mathrm{U}-\mathrm{Pb}$ concordia upper intercept age of $1978 \pm 16 \mathrm{Ma}$, which is presumably related to younger granitic activity that ranges from 2300 to $2100 \mathrm{Ma}$ in the Bastar Craton (Singh et al., 2018).

Various occurrences of uranium (and REE) have been reported by the geoscientists of the Atomic Minerals Directorate for Exploration and Research. These include:surficial U-bearing magnesian-calcrete from Khemasar, Churu district, Rajasthan (Rao et al., 2015); Palaeoproterozoic Khetabari Formation, Bomdila Group, Sie-Rimi area, West Siang district, Arunachal Pradesh (Basu et al., 2015); U mineralization in the basement granitoids from Umthongkut Area, West Khasi Hills District, Meghalaya (Srivastava et al., 2015); U-REE mineralization in the BGC and Delhi rocks in northcentral and northern Rajasthan (Yadav et al., 2015); Uranium mineralization in the carbonate rocks from the upper Krol Formation, Nainital Syncline (Sinha et al., 2016); U mineralization in metasomatized calcsilicate rocks at Raghunathpura, Mahendragarh District, Haryana (Roy et al., 2016); Vein type uranium mineralization in the Paleoproterozoic Bijawar Group of Rocks, Lalitpur District, U.P. (Rawat et al., 2018); granite-hosted pitchblende and coffinite mineralization in the Bhima Basin, Karnataka (Patnaik et al., 2016); U mineralization in the Delhi metasedimentary rocks, Buchera area, Jaipur district, Rajasthan (Patel et al., 2018).

A REE-bearing carbonatite plug that intrudes into the Malani Igneous Suite of rocks and associated with alkaline rocks such as alkali pyroxenite, micromelteigite, nephelinite and phonolite, has been recently 
discovered at Kamthai in the Barmer district Rajasthan. The identified REE phases are bastnäsite, synchysite, carbocernaite, cerianite, ancylite and parisite. The first phase magmatic calcio carbonatite is alvikite type, rich in carbocernaite whereas the second hydrothermal phase, sövite type, is enriched in bastnäsite. With a total REE reserve of 4.91 million tons, Kamthai has the potential to turn into a world class REE deposit (Bhushan, 2015) and also in carrying out research on carbonatite-associated REE mineralization in the coming years. The Siriwasan carbonatite (Gujarat) is sövite and constitutes minerals such as pyroxene, amphibole, apatite, pyrochlore, perovskite and titanite. REE contents in sövites are related to the amount of pyrochlore, perovskite and apatite. The $\mathrm{C}$ - and $\mathrm{O}$ isotope composition of sövite (and ankeritic) plot in the mantle field. However, mixing of carbonatitic melt with surrounding Bagh limestone is also evident. Similarity in $\mathrm{Sr}$ and $\mathrm{Nd}$ isotopic ratios of the Siriwasan and nearby Amba Dongar carbonatites suggest analogous magma source (Viladkar and Gittins, 2016). U- and Ta rich magmatic pyrochlores have been reported from the Newania carbonatite, Udaipur, which underwent hydrothermal alteration that resulted in removal of $\mathrm{Na}, \mathrm{Ca}, \mathrm{F}$ from the A-sites (Viladkar et al., 2017).

Tungsten metallogeny in Rajasthan is characterized by wolframite mineralization in quartz veins associated with S-type granites in Degana, Balda, and Sewariya-Govindgarh. Whole rock Rb-Sr ages for the Balda and Degana granites are respectively $795 \pm 11 \mathrm{Ma}$ and $827 \pm 8 \mathrm{Ma}$, which are casually related to Rodinia breakup (Vijay Anand et $a l, 2018)$. REE modelling of the Sewariya-Govindgarh pluton indicates partial melting in different crustal level for magma generation. Further, the Rb-Sr mineral isochron for the Govindgarh granite furnished an age of $860 \pm 7$ Ma (Sivasubramaniam et al, 2019).

\section{Base Metals}

The Agnigundala Sulfide Belt is situated in the northeastern part of the Cuddapah basin, is perhaps the only Proterozoic analog of the Mississippi Valley Type sulfide deposit in India. The belt constitutes $\mathrm{Cu}$ mineralization at Nallakonda, rare $\mathrm{Cu}-\mathrm{Pb}$ mineralization at Dhukonda, and $\mathrm{Pb}$ mineralization at Bandalamottu. Mineralogical and stable isotope (of $\mathrm{S}, \mathrm{C}$, and $\mathrm{O}$ ) studies suggest that the ore fluid responsible for sulfide mineralization in the Agnigundala Belt was a low-temperature $\left(<200^{\circ} \mathrm{C}\right)$ oxidized fluid. The ore fluid precipitated $\mathrm{Cu}$ at Nallakonda at comparatively higher temperature, also deposited copper-lead at Dhukonda and lead at Bandalamottu under progressive cooling during fluid migration. Sulfur was derived by abiotic thermochemical reduction of basinal water sulfate, and the metals were leached from the lower red-beds with evaporite-bearing continental to shallow marine sediments. Syn-sedimentary faulting caused puncturing of the ore brine pool and migration of the ore fluid through the cover syn-rift sediments undergoing diagenesis. In spite of deformation of the ore bodies, they surprisingly lack significant evidence of sulfide remobilization (Bhattacharya and Bandyopadhyay, 2018).

Cobaltiferous mackinawite and pentlandite occurs in the assemblage chalcopyrite-pyrrhotite \pm pyrite-magnetite-chlorite-blue amphibole (Cl-rich hastingsite -paragasite-sadanagaite) in the MadanKudan mine, Khetri Copper Belt, Rajasthan. The sulfide veins hosting the above assemblage often contain Cl-rich marialitic scapolite, implying vein formation from Cl-rich saline fluid (Baidya et al., 2018). On the basis of mineral replacement texture, and chemical composition, three different types of amphiboles (A1, A2 and A3) were identified in the sulfide-bearing amphibole-feldspathic quartzite from the Kolihan- Chandmari mines, Khetri Copper Belt. While the A1 amphiboles are Fe-Mg-Mn type (cummingtonite-grunerite), the A2 (magnesio-ferrihornblende) and A3 (hastingsite, sadanagaite, tschermakite) amphiboles belong to calcic group. On the basis of modes of occurrence and pertinent mineral replacement textures, the relative timing of formation their established sequence of formation is $\mathrm{A} 1$ followed by A2 followed by A3. The A1 type (Fe-Mg-Mn) is metamorphic, which was replaced by $\mathrm{Ca}$-rich $\mathrm{A} 2$ and both $\mathrm{A} 1$ and $\mathrm{A} 2$ were further replaced by $\mathrm{Na}-\mathrm{Ca}-\mathrm{K}-$ $\mathrm{Cl}$-rich $\mathrm{A} 3$. On the basis of higher $\mathrm{Na}$ and $\mathrm{Cl}$ contents and ubiquitous $\mathrm{Cl}$-rich marialitic scapolite, higher calculated $\mathrm{Fe}^{3+}, \mathrm{Eu} / \mathrm{Ce}$ anomalies, the $\mathrm{A} 3$ amphiboles seem to have precipitated from a saline fluid (evaporite or basinal brine), which was oxidized. Further, from the association of sulfide-oxide mineralization (chalcopyrite- pyrrhotite-magnetitepyrite \pm uraninite \pm allanite) with the $\mathrm{A} 3$ amphibole, the mineralization is proposed to belong to the IOCG 
clan (Baidya et al., 2017).

Trace element chemistry of magnetite in different ore types in the Khetri $\mathrm{Cu}-(\mathrm{Au}, \mathrm{Fe})$ deposit can be used as fingerprints of the ore forming environs. For example, magnetites from the metamorphosed BIF preserve low $\mathrm{Ga}$ and $\mathrm{Ge}$ but high $\mathrm{Ni}, \mathrm{P}$ and $\mathrm{Cu}$ contents compared to hydrothermal magnetite grains. While shearing and associated hydrothermal alteration enriched elements such as $\mathrm{Ni}, \mathrm{P}, \mathrm{Cu}, \mathrm{Al}$ and $\mathrm{Mn}$, elevated contents $\mathrm{Ti}, \mathrm{V}, \mathrm{Co}, \mathrm{Cr}, \mathrm{Ge}$ and $\mathrm{Mg}$ was a consequence of chemical modifications brought in by external fluids.Magnetite composition was primarily controlled by fluid compositions,oxygen fugacity besides minor effects from temperature, fluid-rock interaction and co-precipitating mineral phases (Chen et al., 2015). $\mathrm{Pb}-\mathrm{Pb}$ age of $1362 \pm 29 \mathrm{Ma}$ is obtained in high-Th monazite from Kolihan deposit, Khetri $\mathrm{Cu}$ Belt, may correspond to metamorphism of the host rocks. Hydrothermal monazites from the MadanKudan and Kolihan deposits yielded U-Pb ages of $833 \pm 5$ to $840 \pm 6 \mathrm{Ma}$, which are interpreted to represent the timing of the $\mathrm{Cu}-\mathrm{Ag}$ sulfide mineralization. Since this time slice is well in accordance with the timing of regional $\mathrm{Ca}-\mathrm{Na}$ metasomatism ( $\sim 830$ to $850 \mathrm{Ma}$ ), the metasomatic fluid caused sulfide mineralization in the Khetri $\mathrm{Cu}$ Belt (Li et al., 2019).

Hydrothermal chlorites associated with the $\mathrm{Cu}$ \pm Au mineralization at Thanewasna, Bastar Craton are predominantly chamosite with minor clinochlore. Intra-crystalline chlorite thermometry reveals increase in mean temperature of chlorite formation from $\sim 200$ ${ }^{\circ} \mathrm{C}$ (host rock) to $\sim 230{ }^{\circ} \mathrm{C}$ (proximal alteration) to $\sim 250^{\circ} \mathrm{C}$ (distal alteration), suggesting these chlorites belong to 'high sulfidation epithermal system' (Dora and Randive, 2015). Sulfide mineralization at Thanewasna is characterized by the mineral assemblages of $\mathrm{Cu}-\mathrm{Fe}-\mathrm{Au}-\mathrm{Ag}-\mathrm{Ni}-\mathrm{Ba}-\mathrm{REE}$ minerals typical of IOCG type, which is further supported by magnetite chemistry (Dora et al., 2017)

From the occurrence barite, Ba-calcite, celsian, hyalophane, phlogopite and pyrite, Pruseth et al. (2016) proposed barite dissolution reaction that facilitated $f \mathrm{~S}_{2}$ increase during metamorphism of stratiform massive sulfide ores at Rajpura-Dariba, which in turn triggered sulfide partial melting in the $\mathrm{ZnS}-\mathrm{PbS}-\mathrm{Cu}_{2} \mathrm{~S}-\mathrm{FeS}_{2}-\mathrm{S}$ system. Results of melting experiments elucidated the observed mineral paragenesis of the strata-transgressive vein ores. A $\mathrm{Zn}-\mathrm{Fe}-\mathrm{S}$ melt with minor $\mathrm{Pb}, \mathrm{Sb}$ and $\mathrm{Cu}$ but no $\mathrm{Ag}$ fractionated from an initial melt in the above system forming a residual immiscible sulfosalt-bearing $\mathrm{PbS}$ melt. The final metallic melts, represented by formation of dyscrasite $\left(\mathrm{Ag}_{3} \mathrm{Sb}\right)$ from the sulfosalt-bearing melt and breithauptite $(\mathrm{NiSb})$ or ullmannite (NiSbS) from the sulfosalt-absent melt, were a product of independent fractional crystallization of the immiscible sulfide and $\mathrm{PbS}$-sulfosalt melts.

Phase relations in the $\mathrm{Sb}$-rich half of the $\mathrm{Ni}-\mathrm{Sb}$ $(+\mathrm{Ag})$ at $600{ }^{\circ} \mathrm{C}$ are dominated by a melt field and imply that the breithauptite, $\mathrm{Sb}-\mathrm{Ni}$ phases, $2 \mathrm{FeS} . \mathrm{Ag}_{2} \mathrm{~S}$, $2 \mathrm{Ag}_{2} \mathrm{~S}$.FeS, (Fe,Ag)S, $3 \mathrm{PbS} . \mathrm{Ag}_{2} \mathrm{~S}, \mathrm{CuPbSbS}_{3} \cdot \mathrm{Ag}_{2} \mathrm{~S}$, a $\mathrm{Sb}-\mathrm{Ni}-\mathrm{Ag}-\mathrm{Fe}-\mathrm{S}$ phase, and a $\mathrm{Ag}-\mathrm{Sb}-\mathrm{Ni}-\mathrm{Cu}-\mathrm{Fe}-\mathrm{S}$ phase encountered at Sindesar-Khurd (Rajasthan) signify a disequilibrium assemblage formed by direct crystallization from or by the reaction of a sulfide partial melt with major sulfide phases such as galena and pyrrhotite. Melt generation with compositions close to $\mathrm{CuPbSbS}_{3} . \mathrm{Ag}_{2} \mathrm{~S}$ implies that while the $\mathrm{Pb}$ bearing phases might have crystallized from a melt, which was dominated by $\mathrm{PbS}$, the Fe-bearing phases resulted due to reaction of this melt with pyrrhotite. The Sb-Ni phases associated with breithauptite are perhaps non-stoichiometric. Nisbite $\left(\mathrm{NiSb}_{2}\right)$ produced from an initially Ag-poor Ni-rich melt that produced a residual melt with 33.33 at. $\% \mathrm{Ni}$, after $\mathrm{Ag}$ fractionation. The presence of high $\mathrm{Sb}$ in the $\mathrm{Sb}-\mathrm{Ni}$ phases compared to that in nisbite also suggests that these phases could have formed by the removal of Ag from relatively $\mathrm{Ni}$-poor melts that would have coexisted with breithauptite, confirms the hypothesis of melt-induced sulfide remobilization at Sindesar-Khurd. The presence of breithauptite in remobilized ores associated with metamorphosed massive sulfide deposits possibly indicates sulfide partial melting (Govindarao et al., 2017). Despite being a commonly observed textural feature in sulfide deposits, chalcopyrite disease (in sphalerite) has not been convincingly explained as yet. Experiments were conducted in the system $\mathrm{ZnS}-\mathrm{PbS}$ $\mathrm{FeS}-\mathrm{Cu}_{2} \mathrm{~S}-\mathrm{As}_{2} \mathrm{~S}_{3}$ at $600^{\circ} \mathrm{C}$ and the run products, along with the obtained melt, were annealed at $350{ }^{\circ} \mathrm{C}$, to appraise the role of sulfide partial melting in the formation of chalcopyrite disease. Chalcopyrite blebs developed only in S-rich sphalerites, as a consequence of nonstoichiometry-driven diffusion of $\mathrm{Cu}$. Thus, the 
mechanism involving sulfide partial melting is the primary causative factor behind the development of chalcopyrite disease in sphalerite. Accordingly, chalcopyrite disease may be used as an easily identifiable potential indicator of sulfide partial melting in metamorphosed massive sulfide deposits (Govindarao et al., 2018).

\section{References}

Baidya A S, Paul J, Pal D C and Upadhyay D (2017) Mode of occurrences and geochemistry of amphibole in the KolihanChandmari copper deposits, Rajasthan, India: insight into the oreforming process Ore Geology Reviews 801092 1110

Baidya A S, Sen A and Pal D C (2018) Textures and compositions of cobalt pentlandite and cobaltianmackinawite from the Madan-Kudan copper deposit, Khetri Copper Belt, Rajasthan, India Jour of Earth SystemScience 127 (doi.org/ 10.1007/s12040-018-0954-z)

Basu B, Sharma M, Gupta C S, Thippeswamy S, Jeyagopal A V, Joshi G B and Mohanty R (2015) Uranium mineralization in Paleoproterozoic Khetabari Formation, Bomdila Group, Sie-Rimi area, West Siang district, Arunachal Pradesh Current Science 108 1216-1218

Bhattacharya H N and Bandyopadhyay S (2018) Genesis of copper-lead mineralization in the regionally zoned Agnigundala Sulfide Belt, Cuddapah Basin, Andhra Pradesh, India Mineralium Deposita 53 1213--1230

Bhushan S K (2015) Geology of the Kamthai rare earth deposit Journal of Geological Society of India 85 537-546

Chakravarti R, Singh S, Venkatesh A S, Patel K and Sahoo P R (2018) A modified placer origin for refractory gold mineralization within the Archean radioactive quartzpebble conglomerates from the eastern part of the Singhbhum Craton, India Economic Geology 113 579-596

Chen W T, Zhou M-F, Li X, Gao J-F and Hou K (2015) In-situ LA-ICP-MS trace elemental analyses of magnetite: $\mathrm{Cu}$ $(\mathrm{Au}, \mathrm{Fe})$ deposits in the Khetri copper belt in Rajasthan Province, NW India Ore Geology Reviews 65 929-939

Chinnasamy S S and Mishra B (2017) Genetic implications of fluid-deposited disordered graphite and methane-rich inclusions in the Jonnagiri granodiorite-hosted gold deposit, Eastern Dharwar Craton, India Ore Geology Reviews 89 587-593

Deb M and Pal T (2015) Mineral potential of Proterozoic intracratonic basins in India, In: Mazumder R, Eriksson, PG (eds) Precambrian Basins of India: Stratigraphic and Tectonic Context Geological Society of London Memoirs
43 309-325

Deb M and Sarkar S C (2107) Minerals and allied natural resources and their sustainable development.Principles, perspectives with emphasis on the Indian Scenario Springer Nature Singapore Pte Ltd, 569p.

Dharma Rao C V, Santosh M and Tang Y-J (2015) Re-Os isotope systematics of Archean chromitites from the Chimalpahad Anorthosite Complex, south-east India: Implications for mantle extraction processes Ore Geology Reviews $65274-$ 282

Dora M L and Randive K R (2105) Chloritization along the Thanewasna shear zone, Western Bastar Craton, Central India: Its genetic linkage to $\mathrm{Cu}-\mathrm{Au}$ mineralization Ore Geology Reviews 70 151-172

Dora M L, Randive K R, Ramachandra H M and Suresh G (2017) Iron oxide-copper-gold mineralization at Thanewasna, western Bastar Craton Current Science 112 1045-1050

Ganguly S, Manikyamba C, Saha A, Lingadevaru M, Santosh M, Rambabu S, Khelen A C, Purusotham D and Linga L (2016) Geochemical characteristics of gold-bearing boninites and banded iron formations from Shimoga greenstone belt, India: Implications for gold genesis and hydrothermal processes in diverse tectonic settings Ore Geology Reviews 73 59-82

Govinarao B, Parihar R, Pruseth K L and Mishra B (2017) The occurrence of breithauptite and nisbite-like Sb-Ni phases at Sindesar-Khurd, Rajasthan, India: implications for meltassisted sulfide remobilization Canadian Mineralogist $\mathbf{5 5}$ $75-87$

Govinarao B, Pruseth K L and Mishra B (2018) Sulfide partial melting and chalcopyrite disease: An experimental study American Mineralogist 103 1200-1207

Hazarika P, Pruseth K L and Mishra B (2015a) Neoarchean Greenstone Metamorphism in the Eastern Dharwar Craton, India: Constraints from Monazite $\mathrm{U}-\mathrm{Th}-\mathrm{Pb}_{\text {total }}$ ages and PT pseudosection calculations Journal of Geology 123 429-461

Hazarika P, Mishra B and Pruseth K L (2015b) Diverse tourmaline compositions from orogenic gold deposits in the HuttiMaski greenstone belt, India: Implications for sources of ore-forming fluids Economic Geology 110 37-353

Hazarika P, Mishra B and Pruseth K L (2016) Scheelite, apatite, calcite and tourmaline compositions from the late Archean Hutti orogenic gold deposit: Implications for analogous two stage ore fluids Ore Geology Reviews 72 989-1003

Hazra S, Ray J, Manikyamba C, Saha A and Sawant S S (2015) Geochemistry of PGE in mafic rocks of east Khasi Hills, Shillong Plateau, NE India Journal of Earth System Science 124 459-475 
Jena M S, Mohanty J K, Venugopal R and Mandre N R (2016) Characterization of lowgrade PGE ores of Baula-Nuasahi Area, Odisha, India and implication on beneficiation Ore Geology Reviews 72 629-640

Kesarwani M, Sarangi S, Srinivasan R R, George B G, Singh S K, Bhattacharya S and Vasudev V N (2019) Origin of granodiorite hosted Neoarchean orogenic gold ore deposits: stable isotopic and geochemical constraints with example from the Dharwar Craton, southern India Ore Geology Reviews 107 754-779

Laxman M B and Vijaya Kumar K (2018) Geochemical evidences for possible absence of $\mathrm{Cu}$-sulfide deposits in the Deccan Volcanic Province, India Journal of Geological Society of India 92393-403

Li X-C, Zhou M-F, Wiliam-Jones A E, Yanga Y-H and Gao J-F (2019) Timing and genesis of $\mathrm{Cu}-(\mathrm{Au})$ mineralization in the Khetri Copper Belt, northwestern India: constraints from in situ $\mathrm{U}-\mathrm{Pb}$ ages and $\mathrm{Sm}-\mathrm{Nd}$ isotopes of monazite(Ce) Mineralium Deposita 54 553-568

Maibam B, Foley S, Luguet A, Jacob D E, Singh T B, Ray D, Panda D K and Keppler R Characterisation of chromites, chromite hosted inclusions of silicates and metal alloys in chromitites from the Indo-Myanmar ophiolite belt of North eastern India Ore Geology Reviews 90 260-273

McCuaig T C and Kerrich R (1998) P-T-tdeformation-fluid characteristics of lode gold deposits: evidence from alteration systematics Ore Geology Reviews 12 381-453

Mishra B (2015) Precambrian metallic mineralization in India, In: Mazumder R, Eriksson, PG (eds) Precambrian basins of India: stratigraphic and tectonic context Geological Society of London Memoirs 43 327-337

Mishra B and Hazarika P (2016) Rare greenockite (CdS) within the chromite-PGE association in the Bangur Gabbro, BaulaNuasahi Complex, Eastern India Ore Geology Reviews 72 1327-1334

Mishra B, Pruseth K L, Hazarika P and Chinnasamy S S (2018) Nature and source of the ore-forming fluids associated with orogenic gold deposits in the Dharwar Craton, Geoscience Frontiers 9 715-726

Mondal S K, Khatun S, Prichard H M, Satyanarayanan M and Ravindra Kuamar G R (2019) Platinum-group element geochemistry of boninite-derived Mesoarchean chromitites and ultramafic-mafic cumulate rocks from the Sukinda Massif(Orissa, India) Ore Geology Reviews 104 722-744

Mukherjee R, Venkatesh A S and Fareeduddin (2017) Chemistry of magnetite-apatite from albitite and carbonate-hosted Bhukia gold deposit, Rajasthan, western India - An IOCGIOA analogue from Paleoproterozoic Aravalli Supergroup:
Evidence from petrographic, LA-ICPMS and EPMA studies Ore Geology Reviews 91 509-529

Mukhopadhyay J, Mishra B, Chakrabarti K, De S and Ghosh G (2016) Uraniferouspaleoplacers of the Mesoarchean Mahagiri Quartzite, Singhbhum craton, India: Depositional controls, nature and source of $>3.0 \mathrm{Ga}$ detrital uraninites Ore Geology Reviews 72 1290-1306

Ozha M K, Mishra B and Jeyagopal A V (2016) Reaction aureoles around uraninites within biotite and plagioclase: evidence of low-temperature sequential fluid alteration and LREEmobilization from monazite Mineralogical Magazine $\mathbf{8 0}$ $567-584$

Ozha M K, Pal D C Mishra B, Desapati T and Shaji T S (2017) Geochemistry and chemical dating of uraninite in the Samarkiya area, central Rajasthan, northwestern IndiaImplication for geochemical and temporal evolution of uranium mineralization Ore Geology Reviews 88 23-42

Pal D C and Bhowmick T (2015) Petrography and microthermometry of fluid inclusions in apatite in the Turamdih uranium deposit, Singhbhum Shear Zone, eastern India - an insight into ore forming fluid Journal of Geological Society of India 86 253-262

Pal D, Chinnasamy S S, Goon S, John M M and Ghosh S (2019) Alteration mineralogy, fluid inclusions and stable isotope studies from Chigargunta and Bisanatham gold deposits, South Kolar Greenstone Belt, Dharwar Craton, India: Implications on genesis of gold mineralization Ore Geology Reviews 111 (in press).

Patel A K, Yalia H, Verma M B, Jain A K and Nanda L K (2018) Uranium mineralization in metasediments of North Delhi Fold Belt of Buchara area, Jaipur district, Rajasthan, India Current Science 114 2437-2439

Patnaik S, Hegde G N, Pannerselvem A, Verma M B, Mohany Rand Rai A K (2016) Geochemical behaviour of LREE, Y and $\mathrm{Zr}$ in uranium mineralized and non-mineralized granite from Darshanapur area, in the Gogi- Kurlagere fault zone, Bhima Basin, Yadgiri district, Karnataka Journal of Geological Society of India $\mathbf{8 8}$ 151-158

Prichrd H M, Mondal S K, Mukherjee R, Fisher P C and Giles N (2018) Geochemistry and mineralogy of $\mathrm{Pd}$ in the magnetitite layer within the upper gabbro of the Mesoarchean Nuasahi Massif (Orissa, India) Mineralium Deposita 53 547-564

Pruseth K L, Mishra B, Jehan N and Kumar B (2016) Evidence of sulfide melting and melt fractionation during amphibolite facies metamorphism of the Rajpura-Dariba polymetallic sulfide ores Ore Geology Reviews 72 1213-1223

Rao A Y, Vijay Raj K, Yadav O P, Nanda L K, Rai A K and Parihar 
P S (2015) Uranium-bearing magnesian-calcrete in surficial environment from Khemasar, Churu district, Rajasthan, India Current Science 108 1540-1544

Rawat T P S, Roy M and Joshi G P (2018) Hydrothermal fracture controlled vein type uranium mineralization in the Paleoproterozoic Bijawar Group of rocks, Sonrai Basin, Lalitpur district, U.P. - fresh findings from subsurface borehole data Journal of Geological Society of India $9125-$ 31

Rogers A J, Kolb J, Meyer F M and Vennemann T (2013) Two stages of gold mineralization at Hutti mine, India Mineralium Deposita 48 99-114

Saha A, Manikyamba C, Santosh M, Ganguly S, Khelen A C and Subramanyam K S V (2015) Platinum Group Elements (PGE) geochemistry of komatiites and boninites from Dharwar Craton, India: Implications for mantle melting processes Journal of Asian Earth Sciences 105 300-319

Sahoo AK, Krishnamurthi R, Vadlamani R, Pruseth K L, Narayanan M, Varghese S and Pradeepkumar T (2016) Genetic aspects of gold mineralization in the Southern Granulite Terrain, India Ore Geology Reviews 72 1243-1262

Saravanan C S, Mishra B and Jairam M S (2009) P-T conditions of mineralization in the Jonnagirigranitoid-hosted gold deposit, eastern Dharwar Craton, southern India: Constraints from fluid inclusions and chlorite thermometry Ore Geology Reviews 36 333-349

Singh M R, Manikyamba C, Ray J, Ganguly S, Santosh M, Saha A, Rambabu S and Sawant S S ( 2016) Major, trace and platinum group element (PGE) geochemistry of Archean Iron Ore Group and Proterozoic Malangtolimetavolcanic rocks of Singhbhum Craton, Eastern India: Inferences on mantle melting and sulphur saturation history Ore Geology Reviews 72 1263-1289

Singh Y, Pandit P S C, Bagora S and Jain P K (2017) Mineralogy, geochemistry, and genesis of co-genetic granite-pegmatitehosted rare metal and rare earth deposits of the Kawadgaon area, Bastar Craton, central India Journal of Geological Society of India 89 115-130

Singh Y, Sastry D V L N, Bagora S, Pandit P S C, Rai S D and Verma M B (2018) Dating of columbite-tantalite and monazite from pegmatites of the Kawadgaon-Challanpara area, Bastar Craton, central India Journal of Geological Society of India $\mathbf{9 2}$ 7-10

Sivasubramaniam R, Vijay Anand S, Pandian M S and Balakrishnan $\mathrm{S}$ (2019) Geological, geochemical and $\mathrm{Rb}-\mathrm{Sr}$ isotopic studies on tungsten mineralized Sewariya-Govindgarh granites of Delhi Fold Belt, Rajasthan, NW India Journal of Earth System Science 128 (in press, doi.org/10.1007/ s12040-018-1034-0)

Srivastava S K, Hamilton S, Nayak S, Pandey U K, Mohanty R and Umamaheswar K (2015) Petrography, geochemistry and $\mathrm{Rb}-\mathrm{Sr}$ geochronology of the basement granitoids from Umthongkut area, West Khasi Hills district, Meghalaya, India: implications on petrogenesis and uranium mineralization Journal of Geological Society of India $\mathbf{8 6}$ $59-70$

Swain S K Sarangi S, Srinivasan R, Sarkar A, Bhattacharya S, Patel S C, Pasayat R M and Sawkar R H (2015) Isotope ( $\mathrm{C}$ and $\mathrm{O}$ ) composition of auriferous quartz carbonate veins, central lode system, Gadag Gold Field, Dharwar Craton, India: Implications to source of ore fluids Ore Geology Reviews 70 305-320

Swain S K, Sarangi S, Srinivasan R, Sarkar A, Kesarwani M, Mazumdar A and Satyanarayanan M (2018) Stable isotope (C-O-S) and geochemical studies of auriferous quartz carbonate veins, Neoarchean orogenic Ajjanahalli and Gadag Gold Field, Chitradurga schist belt, Dharwar Craton, southern India: Implication for the source of gold mineralizing fluids Ore Geology Reviews 95 456-479

Ugarkar A G, Malapur M A and Chandan Kumar B (2016) Archean turbidite hosted orogenic gold mineralization in the Gadag greenstone belt, Western Dharwar Craton, Peninsular India Ore Geology Reviews 72 1224-1242

Vijay Anand S, Pandian M S, Balakrishnan S and Sivasubramaniam $\mathrm{R}$ (2018) Fluid inclusion, geochemical, $\mathrm{Rb}-\mathrm{Sr}$ and $\mathrm{Sm}-\mathrm{Nd}$ isotope studies on tungsten mineralized Degana and Balda granites of the Aravalli craton, NW India Journal of Earth System Science 127 1-20

Viladkar S G and Gittins J (2016) Trace Elements and REE Geochemistry of Siriwasan carbonatite, Chhota Udaipur, Gujarat Journal of Geological Society of India 87 709-715

Viladkar S G, Bismayer U and Zietlow P(2017) Metamict U-rich Pyrochlore of Newania Carbonatite, Udaipur, Rajasthan Journal of Geological Society of India 89 133-138

Yadav G S, Muthamilselvan A, Shaji T S, Nanda L K and Rai A K (2015) Recognition of a new albitite zone in northern Rajasthan: Its implications on uranium mineralization Current Science 108 1994-1998

Yadav G S, Pandey U K, Aravind S L, Panchal P K, Venkatesh A S, Sahoo P R, Chaturvedi A K, Rai A K and Parihar P S (2016) U-Pb, $\mathrm{Pb}-\mathrm{Pb}$ and $\mathrm{Sm}-\mathrm{Nd}$ ages of davidite within albitite zone from Bichun, Jaipur district, Rajasthan, India: possible link between uranium mineralization and Grenvillian orogeny Current Science 111 907-913. 